\title{
Assessment of Ecotourism Attractions and Visitors' Satisfaction in Ezeagu Tourist Complex of Enugu State, Nigeria
}

\author{
Henry Mmaduabuchi Ijeomah ${ }^{1}$, Sodienye Augustine Abere ${ }^{2}$, Linda Odinaka Ugwu ${ }^{1}$ \\ ${ }^{I}$ Department of Forestry and Wildlife Management, University of Port Harcourt, P. M. B. 5323 Port Harcourt, \\ Nigeria \\ ${ }^{2}$ Department of Forestry and Environment, Rivers State University, Port Harcourt, Nigeria
}

*Corresponding Author: Henry Mmaduabuchi Ijeomah, Department of Forestry and Wildlife Management, University of Port Harcourt, P. M. B. 5323 Port Harcourt, Nigeria

\begin{abstract}
Various attempts have been made by different levels of government on the creation of awareness towards identifying and developing ecotourism destinations in Nigeria, but the attractions, activities, facilities and tourists' satisfaction level in age - old community-based eco-destinations such as Ezeagu tourist complex are yet to be ascertained. This study therefore assessed the attractions, facilities, activities, and experiences of tourists in Ezeagu tourist complex of Enugu state, Nigeria. Data for this study were obtained through personal observation, in depth interview with staff of the complex, tourists and indigenes of the household who are knowledgeable about tourism; and administration of three sets of questionnaires. A set of questionnaires was purposively administered to 146 household representatives of the host community to collect information on tourist attractions, activities, facilities and experiences. The second set was administered to all the staff of the complex to collect information on frequency of visitation, category of tourists that visit the eco-destination, while the third set was randomly administered to 50 tourists to get information on tourism attractions, available tourism facilities, infrastructures, activities carried out and experiences. Data obtained were analyzed using descriptive statistics in form of frequency of counts, percentages, charts and tables. The major attractions in Ezeagu tourist complex are the Ogbagada waterfall (100\%), Ihu-ogba cave (78.16\%) and Iheneke lake (75.73\%). The main tourism activities in the complex identified by the respondents are swimming (78.64\%), picnicking (52.91\%), fishing (25.24\%), lake viewing (21.84\%), recreation (14.09\%) and research (6.31\%). The major tourism facilities in the complex as identified by tourists are thatched house (34\%) and hanging bamboo bridge (32\%). The preferred period for visitation is mainly during festive period. Ezeagu tourist complex is endowed with unique attractions.
\end{abstract}

Keywords: Ecotourism Attractions, Ezeagu Tourist Complex, Tourist Experience, Enugu State

\section{INTRODUCTION}

The world is endowed with various ecotourism potentials such as waterfalls of different heights and layers; sacred forests of various canopies and layers, caves of different sizes and shapes; lakes of different colors, springs of different temperatures; rivers of different velocities of flow; unique festivals, different cultures, crafts and diverse species of wildlife including endangered, endemic, rare and abundant. These attractive resources are presently being harnessed to develop tourist destinations for aesthetic, educational, recreational, conservational and economic purpose. Visitation to these destinations has become a major source of revenue generation, environmental and cultural sustainability, rural empowerment and employment creation as numerous tourists crave for vivid experience. Creation of ecotourism destinations have become popular as most activities on the planet, earth is being commoditized for revenue generation due to increased capitalistic tendencies. Monetary value is therefore placed on most values that were freely enjoyed in the past. Tourists are now expected to pay for unique experiences - what they see, feel, and touch especially when satisfied (Ijeomah and Herbert, 2012).The willingness of tourists to pay for potential experiences in pristine ecodestinations irrespective of the location is a great motivation for investment in the tourism sector by many stakeholders who are desperately seeking for benefits.

Many countries, states and even local governments have therefore adopted ecotourism as a tool for economic empowerment because of the numerous benefits it generates especially when properly planned, monitored and regulated (Ceballos-Lascurain, 1992; 1996; Ashley, 1999, 2000, 2005; 
Ashley et al., 2000; Honey, 2008; Fiorello and Bo, 2012; Ijeomah and Duke, 2016). With the knowledge of the fact that tourism is the largest market on the planet, earth, and can market any kind of item irrespective of its location the Nigerian Tourism Development Corporation has embarked on a serious search for unique tourism attractions in Nigeria. This is a strategy to develop new destinations and create more opportunities for derivation of benefits.

Creation of new ecodestinations is not an automatic solution to the economic challenges in Nigeria because there are many age - old tourist sites in rural areas, yet the level of poverty in rural areas of Nigeria is increasing progressively. Congestion of most urban areas by unemployed rural immigrants has consistently increased unemployment situation in most cities, whereas abundant ecotourism resources which could be harnessed to create employment opportunities are left undeveloped and unutilized. Many tourist destinations in Nigeria have stopped functioning while some operate at skeletal level (Ijeomah, 2012a; Ijeomah et.al., 2014). Also, many cultural practices in Nigeria such as dances, music, festivals, artworks and languages of indigenous peoples; which could fascinate or excite none natives are at the risk of extinction (UNESCO, 2014).Several studies have been carried out in various eco-destinations especially in areas pertaining to tourism potentials (Ayodele, 2002), impact of tourism (Ijeomah, 2012b), urban tourism, tourism management (Ijeomah and Emelue, 2009), tourism and economic challenges (Ijeomah and Aiyeloja, 2007), but the attractiveness and development of existing age-old community based tourist centers is yet to be properly addressed. The study therefore assesses the tourist attractions, facilities, activities and experience in Ezeagu tourist complex.

\section{METHODOLOGY}

\subsection{Study Area}

Ezeagu tourist complex is located between $7^{\circ} 0^{\prime} 0^{\prime \prime}$ and $7^{\circ} 22^{\prime} 0^{\prime} \mathrm{E}^{\prime}$ and6 $20^{\circ} 30^{\prime \prime}$ and $6^{\circ} 31^{\prime} 30^{\prime \prime} \mathrm{E}$ of Greenwich (Figure 1). It measures about 22 hectares in size (Enugu State Tourism Guide, 2016). Ezeagu tourist complex has three major components: Iheneke lake, Ihu-ogba cave and Ogbagada waterfall (Ezeh, 2006). Ezeagu tourist complex is located in the western part of Obinofia Ndi-Uno community of Ezeagu Local Government Area in Enugu State.

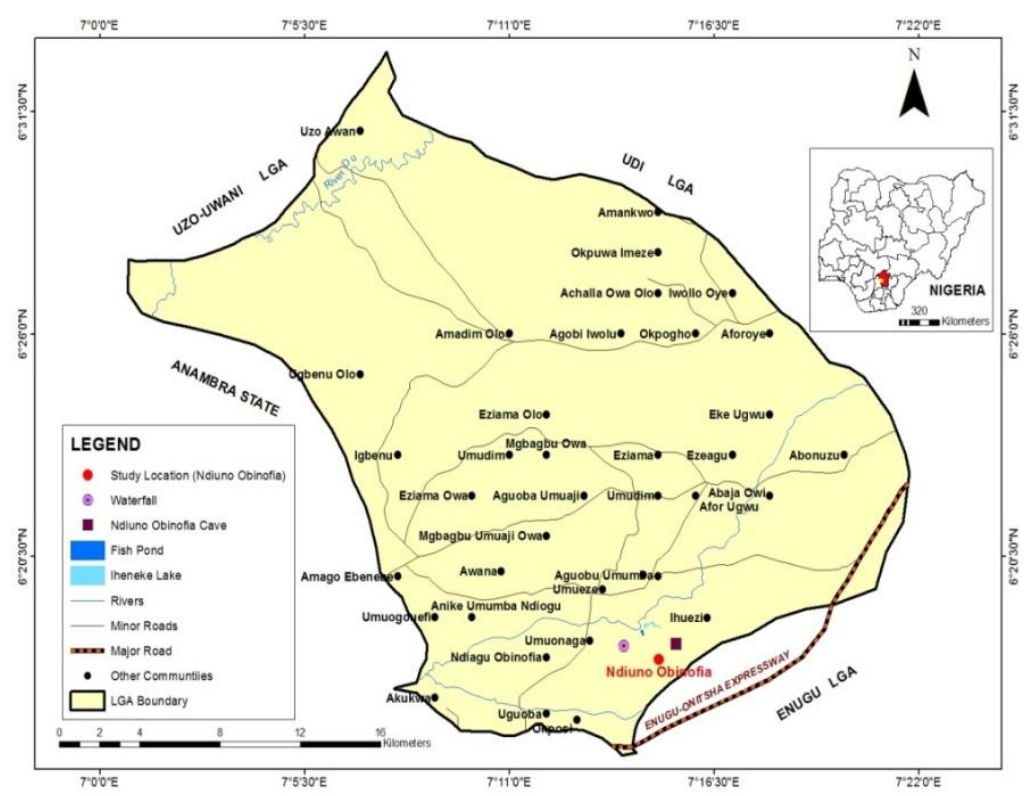

Figure1. Map of Ezeagu Local Government Area showing location of Ezeagu tourist complex

Source: Field Survey, 2016

\subsection{Data Collection}

Data for the study were collected through oral interview, administration of questionnaire and field observation. Three sets of questionnaires were administered for data collection. The first set was administered to representatives of household members of the host community, Obinofia. It was used to collect information on tourism attractions and activities in Ezeagu tourist complex. 
The second set was administered to staff and management of the tourist complex to collect information on category of tourists that visit the eco-destination

The third set was administered to the tourists to obtain information on attractions to Ezeagu tourist complex, their purpose of visit, tourism activities, tourism facilities and tourists' experiences.

\subsection{Sampling Techniques}

Obinofia Ndi - Uno community has five villages, and the five villages are around Ezeagu tourist complex. The villages include Ihuezi, Umuonaga, Umueze, Okposi and Awana. The five villages were selected for data collection from household representatives. A set of 30 questionnaires were purposively administered to the household representatives who have spent a minimum of 10 years in the selected villages. Questions were read out for easy understanding. In all, a total of 150 questionnaires were administered but only 146 were retrieved. The second set of questionnaire was administered to all staff members of the tourist complex. The third set of questionnaire was randomly administered to 50 tourists who are not resident in Obinofia community as shown in Table 1a.

Table1a. Proportional allocation of questionnaires to respondents

\begin{tabular}{|l|l|l|l|}
\hline Set of questionnaire & Number administered & Number retrieved & Total used \\
\hline First set to households & & & \\
\hline Ihueze village & 30 & 30 & \\
\hline Umueze village & 30 & 26 & \\
\hline Umuonaga village & 30 & 30 & \\
\hline Okposi village & 30 & 30 & 146 \\
\hline Awana village & 30 & 30 & 10 \\
\hline Second set-to staff of the complex & 15 & 10 & 50 \\
\hline Third set to tourists & 50 & 50 & \\
\hline
\end{tabular}

Personal interviews were conducted with selected staff members who have worked with the tourist complex for a minimum period of five years and are therefore quite knowledgeable about the management of the tourist complex and also with traditional chiefs who have lived up to a minimum of twenty years in the community to obtain information mainly on the history of the eco-destination and culture of the host community.

\subsection{Method of Data Analysis}

Data obtained from the study were analyzed using descriptive analysis in form of frequencies, percentages and tables.

\section{RESUltS}

\subsection{Tourist Attractions}

Results on tourist attractions are presented in Tables 1 to 7 and Plates 1to11. Table1 shows that the waterfall (Plate 1) is the most popular attraction (100\%) in the destination. Other major attractions in the destination as identified by respondents include the cave $(78.16 \%)$ and lake $(75.73 \%)$ presented in Plates 2 and 3 respectively. Only $2.91 \%$ of the respondents indicated fish pond (Plate 4) as an attraction. According to Table 2, the tourism activity mostly carried out in Ezeagu tourist complex is swimming (78.64\%). Many respondents also participate in picnicking (52.91\%), while some embark on fishing (25.24\%), lake viewing (21.84\%), recreation (14.09\%) and research $(6.31 \%)$. Plates 5 and 6 show some tourists enjoying swimming and picnicking activities respectively in the destination. The thatch house (Plate7), hanging bamboo bridge (Plate 8), narrow iron bridge (Plate 9) and canoe (Plate 10) were identified by all staff respondents as major facilities in the destination (Table 3). However, to tourists, the thatch house $(34.00 \%)$ and Hanging bamboo bridge $(32.00 \%)$ were the major facilities. As presented in Table 4, the time of visitation to Ezeagu tourist complex is mainly during festive periods. Table 5 shows that the reason for festive season as the choice of time for visitation is because many events take place during the period. Table 6 shows that most of the tourists (96.00\%) enjoyed their trip to Ezeagu tourist complex and swimming (76.00\%) was the activity most cherished by respondents. 
Assessment of Ecotourism Attractions and Visitors' Satisfaction in Ezeagu Tourist Complex of Enugu State, Nigeria

Table1b. Tourist attractions in Ezeagu tourist complex as identified by respondents

\begin{tabular}{|l|l|l|}
\hline \multicolumn{1}{|c|}{ Tourist attractions } & \multicolumn{1}{c|}{ Frequency } & \multicolumn{1}{c|}{ Percentage (\%) } \\
\hline Waterfall & 206 & 100.00 \\
\hline Cave & 161 & 78.16 \\
\hline Lake & 156 & 75.73 \\
\hline Bubbling warm spring & 20 & 9.71 \\
\hline Songhai farm & 18 & 8.74 \\
\hline Fish pond & 6 & 2.91 \\
\hline
\end{tabular}

Source: Field survey, 2016

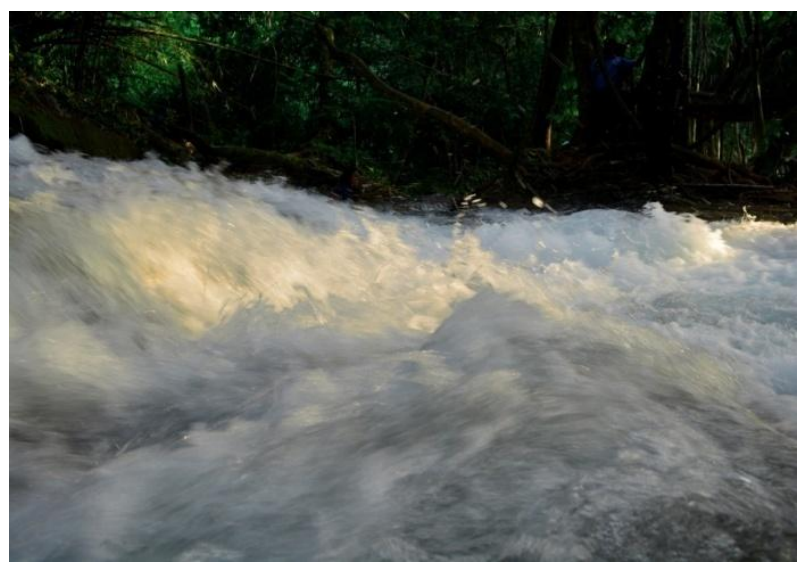

Plate1. Ogbagada waterfall, the main attraction in Ezeagu tourist complex

Source: Field survey, 2016

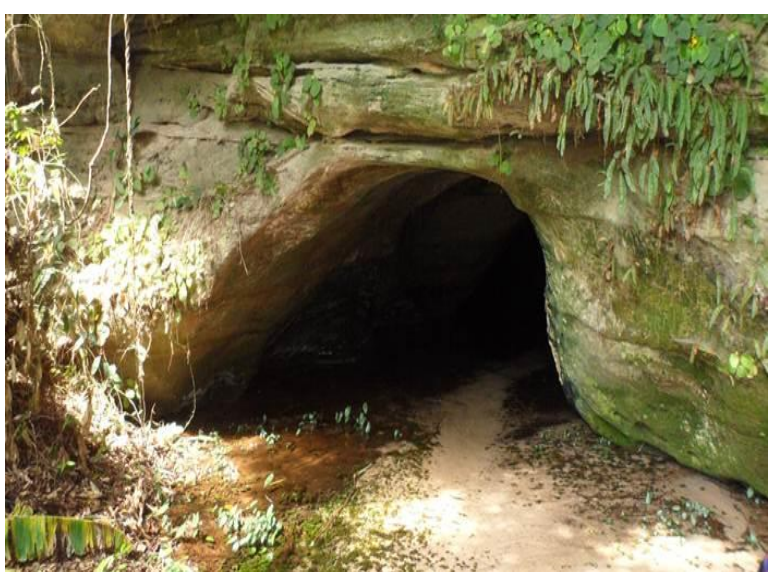

Plate2a. Ihu-ogba cave, an attraction in Ezeagu tourist complex

Source: Field survey, 2016

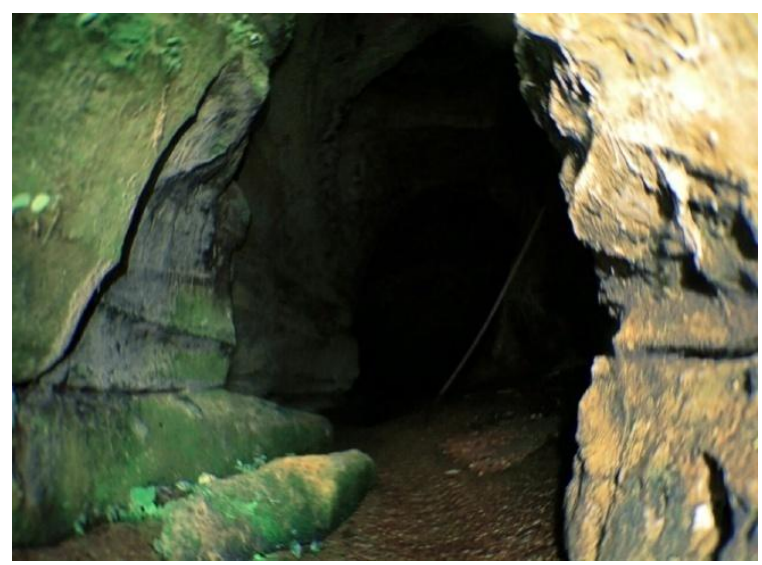

Plate2b. Second entrance to the Ihu-ogba cave

Source: Field survey, 2016

International Journal of Research in Tourism and Hospitality (IJRTH) 


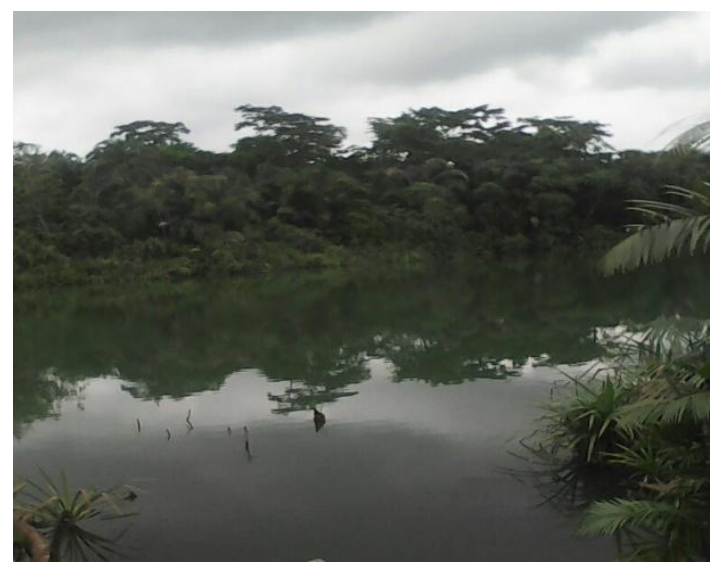

Plate3. Iheneke lake, an attraction in Ezeagu tourist complex

Source: Field survey, 2016

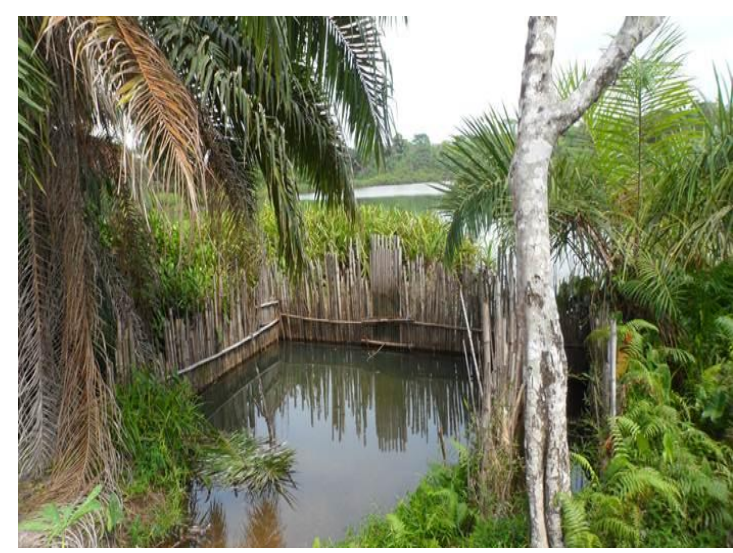

Plate4. Fish pond, an attraction in the complex

Source: Field survey, 2016

Table2. Tourist activities in Ezeagu tourist complex as identified by respondents

\begin{tabular}{|l|l|l|}
\hline \multicolumn{1}{|c|}{ Tourism activities } & \multicolumn{1}{c|}{ Frequency } & \multicolumn{1}{c|}{ Percentage (\%) } \\
\hline Swimming & 162 & 78.64 \\
\hline Picnic/excursion & 109 & 52.91 \\
\hline Fishing & 52 & 25.24 \\
\hline Lake viewing & 45 & 21.84 \\
\hline Recreation & 29 & 14.08 \\
\hline Research & 13 & 6.31 \\
\hline All of the above & 3 & 1.46 \\
\hline
\end{tabular}

Source: Field survey, 2016

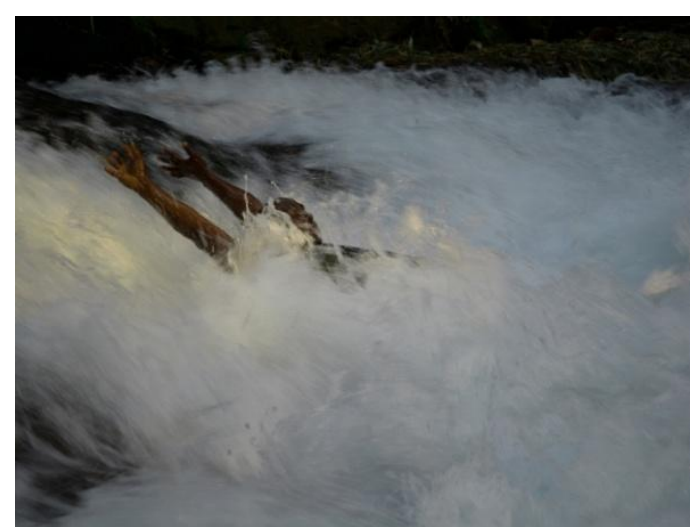

Plate5. Swimming, the most cherished tourism activity in Ezeagu tourist complex

Source: Field survey, 2016

International Journal of Research in Tourism and Hospitality (IJRTH) 


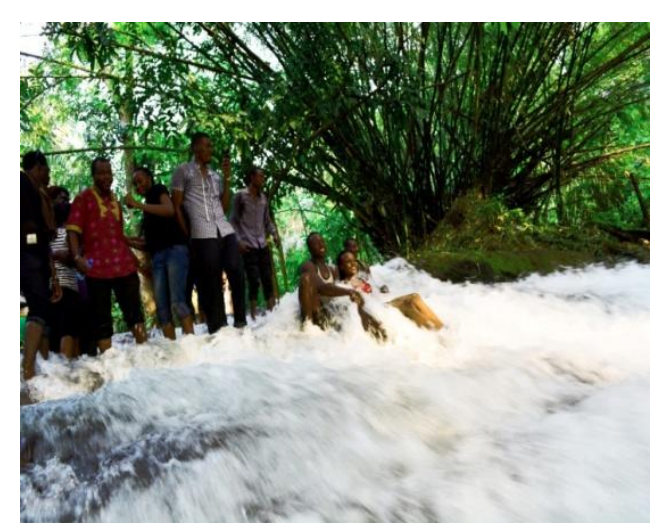

Plate6. Picnicking, one of the main tourism activities in Ezeagu tourist complex

Source: Field survey, 2016

Table3. Tourism facilities in Ezeagu tourist complex as identified by staff and tourist respondents

\begin{tabular}{|l|l|l|l|}
\hline \multicolumn{1}{|c|}{ Assessor } & \multicolumn{1}{c|}{ Tourist facilities } & \multicolumn{1}{c|}{ Frequency } & Percentage (\%) \\
\hline Staff & Thatched house & $10 \quad 100.00$ \\
\hline & Hanging bamboo bridge & 10 & 100.00 \\
\hline & Narrow iron bridge & 10 & 100.00 \\
\hline & Canoe & 10 & 100.00 \\
\hline & Fishing net and lines & 5 & 50.00 \\
\hline Tourists & Thatched house & 17 & 34.00 \\
\hline & Hanging bamboo bridge & 16 & 32.00 \\
\hline & Canoe & 12 & 24.00 \\
\hline & Fishing net and lines & 3 & 6.00 \\
\hline & Narrow iron bridge & 2 & 4.00 \\
\hline
\end{tabular}

Source: Field survey, 2016

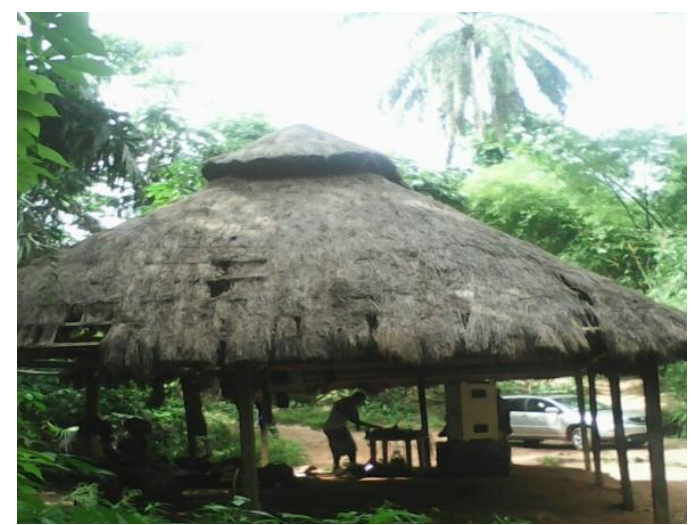

Plate 7: Thatch house, the main tourism facility in Ezeagu tourist complex

Source: Field survey, 2016

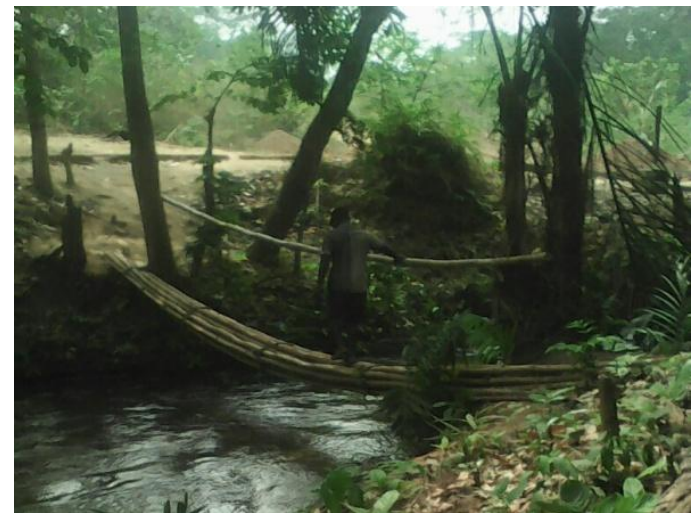

Plate8. Hanging Bamboo Bridge, a tourism facility in Ezeagu tourist complex

Source: Field survey, 2016

International Journal of Research in Tourism and Hospitality (IJRTH) 


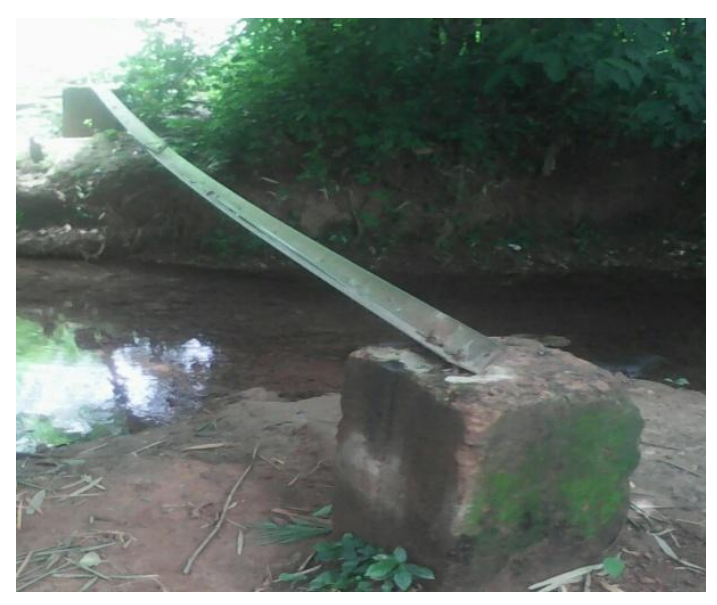

Plate9. Narrow Iron Bridge, a tourism facility in Ezeagu tourist complex

Source: Field survey, 2016

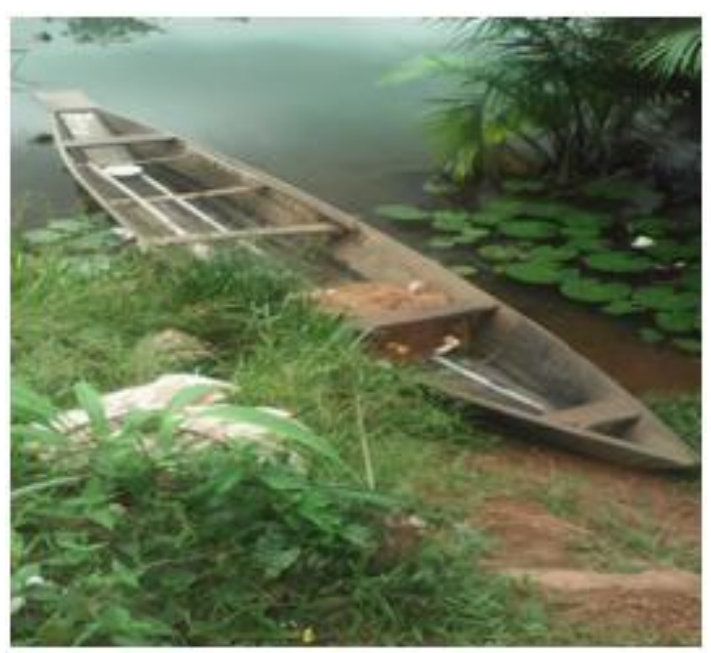

Plate10. Canoe, a fishing facility in Ezeagu tourist complex

Source: Field survey, 2016

Table4. Tourists' preference of time of visitation to Ezeagu tourist complex as identified by respondents

\begin{tabular}{|l|l|l|l|}
\hline \multicolumn{1}{|c|}{ Assessor } & \multicolumn{1}{|c|}{ Preferred time } & Prequency & Percentage (\%) \\
\hline Household & Festive period & 53 & 36.30 \\
\hline & Dry season & 32 & 21.92 \\
\hline & Rainy season & 28 & 19.18 \\
\hline & Weekend & 21 & 14.38 \\
\hline & All year round & 18 & 12.33 \\
\hline Staff & Holidays & 4 & 2.74 \\
\hline & Festive period & 10 & 100.00 \\
\hline & All year round & 10 & 100.00 \\
\hline & Rainy season & 8 & 80.00 \\
\hline Tourists & Dry season & 5 & 50.00 \\
\hline & Holidays & 3 & 30.00 \\
\hline & Rainy season & 17 & 34.00 \\
\hline & Dry season & 11 & 22.00 \\
\hline & Weekend & 7 & 14.00 \\
\hline & Festive period & 6 & 12.00 \\
\hline & All year round & 4 & 8.00 \\
\hline & Others & 3 & 6.00 \\
\hline & Holidays & 2 & 4.00 \\
\hline
\end{tabular}

Source: Field survey, 2016 
Assessment of Ecotourism Attractions and Visitors' Satisfaction in Ezeagu Tourist Complex of Enugu State, Nigeria

Table5. Reason for choice of time of visit by tourists in Ezeagu tourist complex

\begin{tabular}{|l|l|l|l|}
\hline Assessor & \multicolumn{1}{|c|}{ Reasons for choice of time } & Frequency & \multicolumn{1}{|c|}{ Percentage (\%) } \\
\hline Household & Harvest period & 55 & 37.67 \\
\hline & Time for festivals & 49 & 33.56 \\
\hline & When you see the beauty of the place & 35 & 23.97 \\
\hline & More convenient time & 31 & 21.23 \\
\hline Staff & When people visit in mass/meet with friends & 26 & 17.81 \\
\hline & Time for festivals & 8 & 80.00 \\
\hline & Peak period in tourism industry & 3 & 30.00 \\
\hline & When you see the beauty of the place & 1 & 10.00 \\
\hline Tourists & Lore convenient time & 1 & 10.00 \\
\hline & Lots of fun take place & 30 & 60.00 \\
\hline & More convenient time & 11 & 22.00 \\
\hline & When people visit in mass/meet with friends & 9 & 18.00 \\
\hline & Harvest period & 1 & 2.00. \\
\hline
\end{tabular}

Source: Field survey, 2016

Table6. Assessment of tourists' satisfaction in Ezeagu tourist complex as indicated by tourist respondents

\begin{tabular}{|l|l|l|l|}
\hline \multicolumn{1}{|c|}{ Parameter } & \multicolumn{1}{|c|}{ Variable } & \multicolumn{1}{c|}{ Frequency } & \multicolumn{1}{|c|}{ Percentage (\%) } \\
\hline Did you enjoy your trip? & Yes & 48 & 96.00 \\
\hline & No & 2 & 4.00 \\
\hline If yes what did you enjoy? & Swimming & 38 & 76.00 \\
\hline & Get together with friends & 18 & 36.00 \\
\hline & Lake viewing & 10 & 20.00 \\
\hline & Fishing & 2 & 4.00 \\
\hline & People's hospitality & 2 & 4.00 \\
\hline
\end{tabular}

Source: Field survey, 2016

\section{DISCUSSION}

\subsection{Tourists' Attractions}

The major attractions in Ezeagu tourist complex are Ogbagada waterfall (Plate 1), Ihu-ogba cave (Plate 2) and Iheneke lake (Plate 3). The perceived neatness and uniqueness of the waterfall makes tourists visit the complex mostly for swimming (Plate5) and picnicking (Plate 6).The waterfall is about 23 meters high. The water rushes down the cliff with thunderous sound that attracts attention. It is a popular belief among household members of the host community that the waterfall increases to a frightening height when there is noise. This agrees with the report of Enugu State Tourist Guide (2015). The bubbling warm spring also attracts people to the waterfall as it bubbles (Personal observation) with a temperature range of between $40^{\circ} \mathrm{C}$ and $55^{\circ} \mathrm{C}$ (Enugu State Tourist Guide, 2015).

This differs from the Wikki warm spring in Yankari game reserve that has a constant temperature of $31^{\circ} \mathrm{C}$. The bubbling nature of the spring gives it a unique feature when compared with other springs. The cave which is located east of the lake and about $1 \mathrm{~km}$ away from the waterfall has two entrances with three chambers. The first chamber and major entrance (Plate 2a) measures about 3.1 meters in height and 1.8 meters wide, while the second entrance (Plate $2 \mathrm{~b}$ ) measures about 2.8 meters in height and 1.9 meters wide(Enugu State Tourist Guide, 2015). The third and largest chamber is 2, 690 meters wide and 13.2 meters high (Enugu State Tourist Guide, 2015). According to a tour guide, Okeke (Personal communication, 2016) the second chamber is more of a corridor that links the first and third chambers and it is relatively darker than the first chamber. According to Okeke, the third chamber which is the darkest of all was believed to be the habitation place of the spirits of Ogba. In this chamber, visibility is often difficult. The cave inhabits numerous (thousands) bats of different sizes which when disturbed, fly away in mass producing a sound that is synonymous with that of a hurricane(Enugu State Tourist Guide, 2015).The presence, movement and production of sounds by the bats show that the environment is natural and an unaltered habitat. Another notable feature of the cave 
as was observed is that it has an opening at the top from where sun rays lighten the cave. The cave was discovered during the world war when people were looking for where to hide, though information from personal communication revealed that households are yet to ascertain how long the cave has been in existence. According to Ilofar (Personal communication, 2016), the Iheneke lake was formally occupied by Umuagu in Omughu Obeleagu-Umana community and developed overnight after a heavy rainfall. This resulting lake stimulated the departure of the initial inhabitants of the area. This is different from what happened in the environment of Oguta lake where the departure of the original occupants was stimulated by forceful immigration of Oguta community (Ijeomah and Okoli, 2016). The Iheneke lake is a fresh water, covering an area of about $5 \mathrm{sq} . \mathrm{km}$ in length, $45 \mathrm{~km}$ in diameter (Enugu State Tourist Guide, 2016) and inhabits many micro and macro organisms, providing a natural habitat with relatively perceived stable environment. The lake as was observed is surrounded by bamboos (Bambusa vulgaris), raffia palms (Raphia hookeri), oil palms (Elaise guineense), ferns and water lilies. The fish pond (Plate 4) which is also an attraction to few tourists is unique in that it was constructed with bamboo sticks unlike other fish ponds that are constructed with cement. The pond is surrounded by different plant species. The pond reflects the profession of some households in the destination host communities.

Swimming is the major tourism activity in Ezeagu tourist complex (Table 2) as it makes tourists feel cool, refreshed and relaxed. Similarly swimming is the major attraction in Oguta lake. Swimming is not an attraction in Farin Ruwa waterfall of Wamba because of the rocky nature of the water ways (Ijeomah and Alao, 2007). Swimming is not also an attraction in Urashi waterfall ecodestination of Dikenafai as the water does not accumulate in the environment but flows through channels to many other destinations in various communities where it formed big rivers (Ijeomah et al., 2007). Visitation of the complex for the purpose of swimming has been a part of the recreational lifestyle of Ezeagu indigenes. Swimming is often practiced along with water picnicking as tourists engage themselves in sightseeing and taking of photographs. Recreational activities such as relaxation, get together and other forms of entertainment are always practiced in the destination with swimming and picnicking. On the $14^{\text {th }}$ of May, 2016, more than 200 students of Anambra origin from different institutions of higher learning including Nnamdi Azikiwe University, Awka; University of Nigeria, Nsukka; Anambra State University of Science and Technology; Institute for Management and Technology, Enugu etc. gathered in the tourism complex for a picnic (Personal observation).

Fishing and lake viewing are among the major activities carried out in the lake. The amazing nature of direction of flow of the lake attracts tourists from far and near. Tourists spend time viewing the lake and analyzing the mystery behind the direction of its flow. Fishing has been a source of livelihood to the households in the host community as it serves as a source of both food and income. Canoe, fishing net, lines and hooks (Plate 10) are used for fishing in Ezeagu tourist complex. Hunting is also carried out at the cave because of the surrounding vegetation (forests) that inhabits many animal species. Information through personal interaction revealed that by traditional norm only one animal out of the many caught by a hunter can be taken out of the cave premises. Provision was therefore made beside the cave for roasting and consumption of bushmeat meant for consumption in the cave. Roasting and consumption of catches that should not be taken home are experienced therein. This shows that visitation of tourists have not altered the culture of destination host communities unlike in $\mathrm{Sa} \mathrm{Pa}$ of Vietnam where the original intent of the 'love market' was eroded by the introduction of tourism (Koeman,1998; Ijeomah and Alarape, 2009).It also shows that the indigenous people in most communities (eastern Nigeria inclusive) had traditional conservation laws made to check over exploitation of natural resources - in the case of Urashi waterfall of Dikenafai, it was considered a taboo for some nearby communities to visit the destination, and that could be a strategy to reduce overcrowding the environment and the associated regular fights to fetch water during the peak period of water scarcity in the host community. The tourism facilities in Ezeagu tourist complex are thatched house (Plate 7), hanging bamboo bridge (Plate 8), narrow iron bridge (Plate 9) and canoe (Plate10; Table 3). The thatched house serves as a shade anda place for tourists to rest. The presence of the thatched house gives the environment a natural, rural and culturally compatible background. Thatch houses are common in Pandam, the host community to Pandam Wildlife Park, as it brings about 
cooling effect during hot season (Ijeomah and Emelue, 2009). The hanging bamboo bridge is made of bamboo sticks and aids tourists and indigenes of Ezeagu to access the waterfall. Similarly, the narrow iron hanging bridge aids people to access the cave. Walking on both the bamboo bridge and the narrow iron hanging bridge brings a lot of excitement to tourists. Walking on both the bamboo bridge and narrow iron bridge is like an adventure and therefore requires a lot of concentration. Similar suspended linking walkways, the hanging bridge and Kakum canopy walkway exist in Okomu national park of Nigeria and Kakum forest reserve in Ghana respectively. However, these two walkways structurally differ from the ones in Ezeagu tourist complex - they are made with ropes (Ijeomah et al., 2015).Besides, visitors seem to be more protected in these dangling rope - made walkways than the bamboo bridge and narrow iron bridge. There is a shrine at the junction of the cave where sacrifices are offered to the Ogba deity. The shrine is among the section of the destination that is least visited by tourists. This can be attributed to the gradual decline of traditional religion in many areas. Shrines in many tourism sites such as Oguta lake, Urashi waterfall and Farin Ruwa waterfall destinations are of minimal interests to tourists (Ijeomah et al., 2015; Ijeomah and Okoli, 2016).

Visitation to Ezeagu tourist complex is more frequent during festive period when lots of events and festivals take place (Table 4). Masquerade festival, new yam festival and Christmas celebration are among the attractive ceremonies in Ezeagu tourist complex. Many indigenes of Obinofia community visit the community during these periods through invitation for events or functions. In the course of the season, the complex was advertised as a venue for events. The World tourism day celebration held at the complex in 2016. This cannot be unconnected with the fact that the destination is endowed with highly valued tourism virtues of international relevance that needed to be showcased. Similarly, the Farin Ruwa Waterfall served as a site for the national World Tourism Day Celebration of $27^{\text {th }}$ September, 2003 in Nigeria. The festive periods in Obinofia community are usually from December to February for Christmas and valentine season, October to November for masquerade festival and July, August/ September for new yam festival (Personal communication, 2016). Some visitors prefer to visit the complex during the rainy season when the water level is high, thus enhancing the beauty of the destination, and also when they have lots of fun. However, few tourists prefer visiting the tourism complex during the dry season for easy access and convenience (Table 5).

Most tourists always leave the complex happily with memorable experiences. They always comment on the beauty and peaceful nature of the complex and the natural endowments therein. Swimming is an experience cherished by most respondents (Table 6). Swimming brings about a cooling effect on their body. Ijeomah et al (2015) obtained a similar report in Oguta lake Destination. Apart from swimming many tourists enjoy picnicking; which entails meeting with friends in the destination (Plate 6). Enjoyment of picnicking in the destination could be attributed to the fact that when the participants are recreating with friends or colleagues in the natural environment they feel relaxed and forget about other activities that would have been a sort of stress to them. Lake viewing is also an activity that is always memorable to tourists (Table 6). In Farin Ruwa ecodestination of Wamba, waterfall is the major attraction to tourists (Ijeomah and Okoli, 2015). Some tourists enjoyed meeting new friends, taking photographs while involved in fascinating activities that remain memorable.

\section{CONCLUSION AND RECOMMENDATION}

Ezeagu tourist complex is a community-based eco-destination that attracts people from far and near for swimming, picnicking, lake viewing and enjoyment ofcultural festivals such as masquerade festivals, new yam festivals and age grade ogene dance, which are performed to display culture and entertain visitors. The Ogbagada waterfall, Ihu-ogba cave and Iheneke lake are the major attractions in the complex. Thatched house is the most utilized tourism facility by tourists. Both foreign and local investors can be attracted to the complex, when it is adequately developed with standard infrastructures and facilities. This can create employment opportunities and also minimize rural-urban migration.

\section{REFERENCES}

[1] Ashley, C.(1999). Financial and livelihood impacts of butterfly farming at Arabuko Sokoke forest. African Wildlife Foundation, Kenya. 
[2] Ashley, C.(2000). The impacts of tourism on rural livelihoods. Experience in Namibia. Overseas Development Institute (ODI) Working Paper No. 128. London, 31pp.

[3] Ashley, C., Boyd, C. and Goodwin, H. (2000). Pro-poor tourism: Putting poverty at the heart of the tourism Agenda. Overseas Development Institute. London. 13pp.

[4] Ashley, C. (2005). The Indian Ocean Tsunami and Tourism. Over sea Development Institute. www.odi.org.uk/publications/opinion

[5] Ayodele, A.I. (2002). Essentials of Tourism Management. Ibadan Elshaddai global ventures Ltd, Nigeria.90Pp.

[6] Ceballos-Lascurain, H. (1992).Tourists for conservation, Journal of People and Planet, 1(3) :28-30.

[7] Ceballos-Lascurain, H. (Ed) (1996). "Tourism, Ecotourism and Protected Area". International Union for Conservation of Nature and Natural Resources, Gland, Switzerland

[8] Enugu State Tourist Guide (2015). Ezeagu Tourist Complex. Enugu State Tourism Board, Enugu State.

[9] Ezeh, I.A. (2006).Selected Tourist Attractions in Enugu State:Ezeagu tourist complex, Awhum waterfall and Opi Lake system as case studies. M.A.thesis.Department of Archaeology and Tourism, University of Nigeria, Nsukka.pp.56-66.

[10] Fiorello, A. and Bo, D. (2012) Community-based ecotourism to meet the new tourist's expectations: an exploratory study. Journal of Hospitality Marketing \& Management, 21 (7):758-778.

[11] Honey, M. (2008). Ecotourism and sustainable development: who owns paradise? (2 ${ }^{\text {nd }}$ ed.). Washington, DC: Island Press.

[12] Ijeomah, H.M. (2007). Impact of Tourism on Perceived Poverty alleviation in Plateau State, Nigeria, PhD thesis.Department of Wildlife Management and Fisheries, University of Ibadan, Oyo State, Nigeria.301pp.

[13] Ijeomah, H.M. and Aiyeloja, A.A. (2007). Tourism and Economic Challenges in Jos and Pandam Wildlife Parks of Plateau State, Nigeria. Nigerian Journal of Forestry, 37(1):11-18.

[14] Ijeomah, H.M. and Alao, J.S. (2007) Assessment of ecotourism development at FarinRuwa Waterfall in Nasarawa State, Nigeria, Journal of Production Agriculture and Technology, (PAT) 2(3), 162-174.

[15] Ijeomah, H.M. and Emelue, G.U. (2009). "Tourism Management and Sustainability Resource Utilization in Pandam Wildlife Park of Plateau State, Nigeria", Journal of Sustainable Development in Africa, 11(2), 206-222

[16] Ijeomah,H.M. and Alarape, A.A. (2009).Marital Characteristics of Households adjoining Ecotourism Centres in Plateau State: Implications on Rural Tourism Development. Asia- Pacific Journal of Rural Development, 19(2):109 - 12,http://cirdap.org/publications/apjord/,

[17] Ijeomah, H.M. (2012a).Challenges of Game Reserves in Nigeria: A Case Study of Pai River Wildlife Park of Plateau State, Nigeria In: Ijeomah, H.M. and Aiyeloja, A.A.(eds.).Challenges to Sustainable Production in Agriculture and the Environment: Nigeria in Perspective. TopBase Nigeria Limited, Lagos, in Conjunction with Green Canopy Consultants, Port Harcourt, Rivers State

[18] Ijeomah, H.M. (2012b). Impact of tourism on livelihood of communities adjoining ecodestinations in Plateau State, Nigeria. Journal of Cultur (Revista de Cultura e Turismo)6(3):55 -71.

[19] Ijeomah, H.M. and Herbert, B.C. (2012). Reality of Tourism Management: Business Viability and Tourists'Behaviour in Plateau State, Nigeria. Journal of (CulturRevista de Cultura e Turismo) 6(3):18 -35

[20] Ijeomah, H.M., Eniang, E.A., \&Umuokoro, O. (2014).Coastal Tourism in Niger Delta Region of Nigeria (155-164). In O.Y. Ogunsanwo,A.O.Akinwole,I.O.Azeez, V.A.J.Adekunle,\& N.A. Adewole(Eds.), Sudano-Sahelian Landscape and Renewable Natural Resources Development in Nigeria, Proceedings of the $37^{\text {th }}$ Annual conference of the Forestry Association of Nigeria held in Minna, Niger State Between $9^{\text {th }}$ and $14^{\text {th }}$ November, 2014

[21] Ijeomah, H.M., Okoli, C.I.C. and Iyah, E.I. (2014). Ecotourism Resources of University of Uyo, Nigeria: The Arboretum and Ravine Destinations in Perspective. Ethiopian Journal of Environmental Studies and Management 7(3):327-338

[22] Ijeomah, H.M., Nwanegbo, O.C. and Umokoro, O. (2015).Assessment of Tourist Attractions in Okomu national park and Oguta Lake ecodestinations of Nigeria. Production Agriculture and Technology11 (2): 219-239.

[23] Ijeomah, H.M., and Okoli, C.I.C. (2016). Assessment of Tourist Visitation and Host Communities' Participation in the Management of Selected Ecotourism Destinations in Nigeria. International Journal of Research in Tourism and Hospitality 2(1):19-33.

[24] Ijeomah, H.M. and Duke, E.K. (2016). Prospects and Sustainability of Ecotourism in Finima Nature Park, Bonny Island, Rivers State, Nigeria, Journal of Research in Forestry, Wildlife \& Environment 8(4):39-5 
[25] Koeman, A. (1998). Sa Pa, Vietnam: Capacity Building for Sustainable Tourism and Sa Pa, Vietnam: ides for the future. Communications to the internet conference on Community Based Mountain Tourism Sponsored by Mountain Forum, 11 May. Retrieved Feb. 16, 2003 from http://www.2.mtnforum.org/

[26] UNESCO (2014).World culture report: Cultural diversity, conflict, and pluralism. UNESCO, Paris

Citation: Henry Mmaduabuchi Ijeomah, Sodienye Augustine Abere, Linda Odinaka Ugwu. "Assessment of Ecotourism Attractions and Visitors' Satisfaction in Ezeagu Tourist Complex of Enugu State, Nigeria" International Journal of Research in Tourism and Hospitality (IJRTH), vol 4, no. 1, 2018, pp. 33-44. doi:http://dx.doi.org/10.20431/2455-0043.0401005.

Copyright: (C) 2018 Authors. This is an open-access article distributed under the terms of the Creative Commons Attribution License, which permits unrestricted use, distribution, and reproduction in any medium, provided the original author and source are credited. 